\title{
The exotic gastropod Clea helena (von dem Busch, 1847) as a predator of freshwater gastropods: a threat to native biota in India?
}

\author{
Pranesh Paul, Koushik Paul, Rupsha Karmakar, Arnab Shee, Debaditya Kumar, Gautam Aditya* \\ Department of Zoology, University of Calcutta, Ballygunge Circular Road 35, Kolkata - 700019, India, e-mail: gautamad- \\ itya2001@gmail.com (G.A., " ${ }^{*}$ corresponding author)
}

\begin{abstract}
The carnivorous snail Clea (Anentome) helena (von dem Busch, 1847) (Gastropoda: Nassariidae), commonly called as the "assassin snail" is sold worldwide including India for aesthetics and the ability to kill pest snails in aquaria. Assuming invasion as a fair possibility, the predation potential of $C$. helena on seven native freshwater snails was assessed. The exotic predator consumed all the native snail species provided in the experiment and prey consumption varied with the prey species identity, the prey density and the prey size class. Future colonization and establishment of $C$. helena in Indian freshwater ecosystems may reduce the abundance of the native gastropod snails, in absence of suitable intervention.
\end{abstract}

Key words: Assassin snail, biological invasion, ornamental aquaculture, operculate snails, pet trade

\section{Introduction}

The freshwater snails (Mollusca: Gastropoda) are abundant in a wide variety of water bodies comprising of about 4,000 species worldwide (Strong et al. 2008) with approximately 112 species reported from India (Tripathy et al. 2015). The freshwater snails graze upon the periphyton and macrophytes (Li et al. 2009), regulate algal biomass (Pinowska 2002; Rober et al. 2011), serve as prey of several macroinvertebrates and vertebrates (Aditya and Raut 2002a, 2002b; Sin 2006) in freshwater ecosystems. In benthic communities, the snails change the sediment characteristics through bioturbation (Zheng et al. 2011), while the shells of dead snails serve as calcium reservoir and substrate for periphyton growth (Gutiérrez et al. 2003). In recent years, the shells of the freshwater snails are promoted as biosorbent of heavy metal, thereby facilitating the bioremediation of contaminated water bodies (Hossain and Aditya 2013, 2015; Hossain et al. 2015). Although many snails are the intermediate host of trematode parasites of humans and domestic ani- mals (Madsen and Hung 2014), the ecological roles of snails cannot be neglected and can be used as a surrogate species for habitat restoration and conservation (Gutiérrez et al. 2003). Since the year 1500 AD, 267 gastropod species extinction occurred worldwide which is about $35 \%$ of the total number of extinct animals (IUCN 2020). Besides climate change (Botkin et al. 2007) and habitat modification (Fagan et al. 2002), biological invasions are often considered to be one of the leading causes of global biodiversity loss (Mack et al. 2000). The major pathways of exotic freshwater species invasion include several anthropogenic activities (Wilson et al. 2009) such as the import of exotic species for aquaculture, stocking in the garden ponds and international ornamental pet trade (Padilla and Williams 2004; Rixon et al. 2005; Duggan 2010; Ng et al. 2016a; Patoka et al 2017a) which has a direct and lucid relationship with the worldwide spread of exotic species (Burgiel et al. 2006).

Aquarium keeping is a well-admired hobby with millions of aquarium enthusiast worldwide (Novák et al. 2020). Numerous snails are placed 
in aquaria for their aesthetic values and considered beneficial by regulating algal growth but few pest snails damage the ornamental plants. This is where the carnivorous snail Clea (Anentome) helena (von dem Busch, 1847) (Gastropoda: Nassariidae) hitched into the chronicle. Although first described from Indonesia (Philippi 1847), C. helena was later documented from Cambodia, Laos, northern Peninsular Malaysia, Thailand and Vietnam (Chan 1997). Commonly known as the "assassin snail", $C$. helena is kept in aquaria to consume and control the pest snails (Monks 2010). The worldwide use of $C$. helena in the pet trade can serve as a probable dispersal factor beyond its native range. For instance, the ornamental pet trade caused the first non-native establishment of $C$. helena in Singapore $(\mathrm{Ng}$ et al. 2016b) and argued as a threat to native gastropods (Mienis 2011; Bogan and Hanneman 2013). Although reported as having a medium risk of freshwater invasion (Patoka et al. 2017b), C. helena can breed well in the still-water and have adaptability even in captive conditions (Coelho et al. 2013). Many invasive species frequently establish in natural habitats, in absence of any prevention or eradication efforts as the methods are often not costeffective (Lodge et al. 2006). In Indian context, the possible risk of invasion can be expected for the pet snail Pomacea diffusa that was encountered in different aquarium shops since 1999 (Raut and Aditya 1999), consuming wide range of food items (Aditya and Raut 2001a). Similarly, following the first invasion in Kolkata, India (Raut et al. 1995), the globally invasive snail Physella acuta continued to expand its geographical range in different regions and freshwater habitats of this country (Devi et al. 2008; Saha et al. 2016). Although the aquarium industry is worth multi-billion dollar worldwide, the laws regarding the pet supply, stocking and selling are weakly communicated, inadequately enforced and often not aligned with aquarium enthusiast's beliefs (Patoka et al. 2018). Our observations on the trade of $C$. helena in the local pet shops of Kolkata, India, prompted us to assume that the chance dispersal in the local water bodies is a fair possibility. Therefore, it would be a prudent step to evaluate the predation potential of $C$. helena on the native snails of the local freshwater habitats. Using variations in the size class and relative density of the prey, the predatory efficacy of $C$. helena was evaluated against seven different native snail species.

\section{Materials and method}

The exotic snails $C$. helena were brought from the local pet markets in Kolkata, West Bengal, India during December 2019 and January 2020. The stock of $C$. helena was maintained in glass aquaria $(38 \mathrm{~cm}$ length $\times 30 \mathrm{~cm}$ width $\times 30 \mathrm{~cm}$ depth; $\sim 34$ litres capacity) with a stocking density of five individuals per litre of dechlorinated tap water and fed with tubificid worms and snails during the rearing period. The potential freshwater prey snails were collected from several ponds, temporary pools and lakes in and around Kolkata, using a sampling net of 200 $\mu \mathrm{m}$ mesh size fitted with a long handle. The dredging of the benthic sediment enabled the capture of the benthic snail species. The collected snails were placed in polythene bags with adequate water and brought to the laboratory, where these were segregated and maintained separately in plastic tubs. The collection of the snail species was continued throughout the study period to ensure a continuous supply of the prey snails required for the experiment. As prey snail, seven species were considered, namely, Melanoides tuberculata (Müller, 1774) (Caenogastropoda: Thiaridae), Tarebia granifera (Lamarck, 1822) (Caenogastropoda: Thiaridae), Bellamya bengalensis (Lamarck, 1822) (Caenogastropoda: Viviparidae), and Gabbia orcula (Frauenfeld, 1862) (Caenogastropoda: Bithyniidae) among the operculate snails, while the non-operculate snails were Radix rufescens (Gray in Sowerby, 1822) (Heterobranchia: Lymnaeidae) (erstwhile Lymnaea acuminata) (Vinarsky et al. 2020), Indoplanorbis exustus (Deshayes, 1834) (Heterobranchia: Planorbidae), and Gyraulus convexiusculus (Hutton, 1849) (Heterobranchia: Planorbidae). Based on the shell length or shell diameter as applicable, measured (in $\mathrm{mm}$ ) with a vernier caliper (Insize, Brazil), the snail size classes were created and segregated (specified below). Following segregation and before use in the experiments, the snails were placed in glass aquaria filled with dechlorinated tap water.

As a predator, the most abundant size class of $C$. helena (18-24 $\mathrm{mm}$ in shell length) was selected for the experiment. Before the experiment, all $C$. helena individuals were fed ad libitum with prey snail and tubificid worms and then kept for starvation for 24 hours to coequal the hunger level. The prey snails, B. bengalensis, $M$. tuberculata, T. granifera and I. exustus were divided into $3(<8$, 
8.1-12 and $>12.1 \mathrm{~mm}), R$. rufescens was divided into $3(<10,10.1-15$ and $>15.1 \mathrm{~mm})$ and $G$. orcula and $G$. convexiusculus were divided into $2(<5,>5.1$ and $<6,>6.1 \mathrm{~mm}$ respectively) size classes according to their abundance in the collected samples. To evaluate the prey consumption, one $C$. helena individual was placed in plastic containers of $2,000 \mathrm{ml}$ volume with each selected species of prey snails with varying prey densities (i.e. $\mathrm{n}=5,10$ and 20) and size classes. The experiments were carried out in $\mathrm{pH}$ 7.4-7.9, temperature $25 \pm 1^{\circ} \mathrm{C}$ and photoperiod of 14:10 hours (light:dark). The numbers of prey consumed were noted in every 48 hours interval and each trial was replicated at least 50 times for each of the predator and prey combinations. At the end of 48 hours, the prey consumption was noted and recorded for further statistical analysis. In order to ascertain if the prey species, prey size class and prey density had any significant effect on prey consumption by $C$. helena, logistic regression based on binomial generalized linear model with logit link was applied (Casas and Hulliger 1994; McCullagh and Nelder 1989) using XLSTAT version 2010.04.02. The prey consumption was defined as a function of the linear predictors, prey species (PS), prey size class (PSC) and prey density (PD) and the significance of the model parameters was tested through the Wald's Chi-square at $p<0.05$ level.

\section{Results}

The exotic gastropod $C$. helena preyed upon all operculate and non-operculate snail species provided in this experiment (Fig. 1H). Among the operculate prey snails, the predation rate of $C$. helena was observed to be highest in the case of the maximum prey density $(\mathrm{n}=20)$ of the smallest size class $(<8 \mathrm{~mm})$ of $B$. bengalensis. The consumption of $B$. bengalensis by $C$. helena varied from $0.18( \pm 0.054)$ $( \pm \mathrm{SE})$ to $3.2( \pm 0.318)$ (Fig. 1A). Following the highest predation rate on $B$. bengalensis per 48 hours, $C$. helena consumed $0.84( \pm 0.119)$ to $1.52( \pm 0.202) G$. orcula (Fig. 1D) and $0.26( \pm 0.062)$ to $1.38( \pm 0.158)$ M. tuberculata (Fig. 1B). The lowest predation rate of $C$. helena per 48 hours was observed in the case of the thiarid snail $T$. granifera, which varied from 0.22 $( \pm 0.065)$ to $0.84( \pm 0.122)$ (Fig. $1 \mathrm{C})$. Amid the nonoperculate snails, the consumption by $C$. helena was highest in the case of $I$. exustus with the consumption of $0.64( \pm 0.119)$ to $2.02( \pm 0.205)$ individuals in 48 hours period (Fig. 1F). Following I. exustus, $C$. helena consumed $0.92( \pm 0.133)$ to $1.68( \pm 0.177)$ $G$. convexiusculus (Fig. $1 \mathrm{E})$ and $0.08( \pm 0.038)$ to $1.26( \pm 0.15) R$. rufescens in 48 hours period (Fig. $1 \mathrm{G)}$. The predation posture of the snail $C$. helena against the subdued prey is shown in Figure $1 \mathrm{H}$. As indicated through the results of logistic regression, prey consumed $(y)=1 /(1+\exp (-(-7.14-0.02 P S$ -0.63 PSC $+0.18 \mathrm{PD})$ )), the prey consumption of C. helena varied significantly with the prey species, prey size and prey density (PS $=-0.023 \pm 0.011$; Wald's chi square $=4.698 ; \mathrm{p}=0.03 ; \mathrm{PSC}=-0.274$ \pm 0.012 ; Wald's chi-square $=482.242 ; \mathrm{p}<0.0001$; $\mathrm{PD}=0.08 \pm 0.01 ;$ Wald's chi-square $=52.025 ; \mathrm{p}$ $<0.001)$.

\section{Discussion}

The shell morphology and structure, in general, play an important role to reduce the predation pressure, as observed for $P$. acuta against the malacophagous leech (Wilken and Appleton 1991). Further, the thick shells and spikes resist the predation from shell-crushers (Marijnissen et al. 2008) and the presence of operculum resist the invasion of shell-invader predators (Kelly and Cory 1987). In the Indian context, the shell-invader predators in freshwater habitats, mainly composed of leeches and hemipteran bugs (Aditya and Raut 2002a, 2002b), often fail to make successful attack on the native operculate snails (Aditya and Raut 2005). However, the predatory snail $C$. helena was able to insert its proboscis and kill the operculate prey snails, which otherwise seemed to be less probable for a native shell-invader predators of India. Therefore, the exotic predator $C$. helena may gain more advantage than the native predators if invades into natural habitats.

A major portion of molluscs sold in the local markets of West Bengal consists of the snail $B$. bengalensis which is nutrient-rich as well as possess ethnomedicinal values (Bhattacharya et al. 2014). The waste shells of $B$. bengalensis derived thereof bear the potential of heavy metal biosorption (Aditya and Hossain 2018). The snail, $B$. bengalensis is a dioecious and viviparous snail that discharges fully developed offspring of about $3 \mathrm{~mm}$ shell length (Khan and Chaudhuri 1984). The late-juvenile and early-adult constitute the major proportion of the $B$. bengalensis population, as the juvenile mortal- 


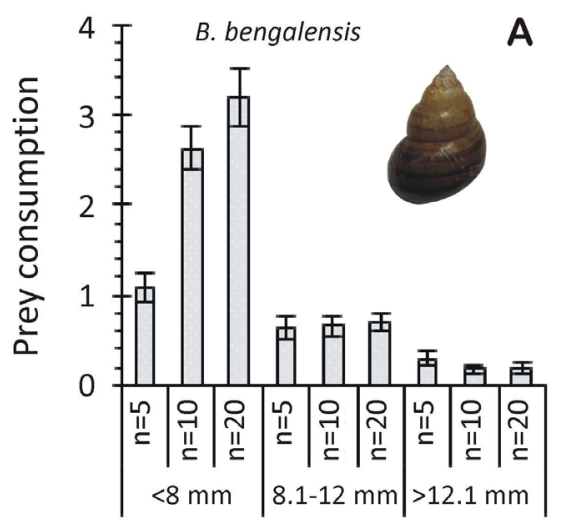

Prey size density

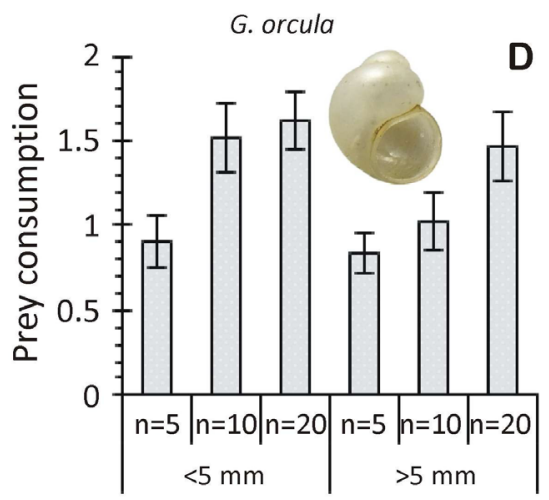

Prey size density

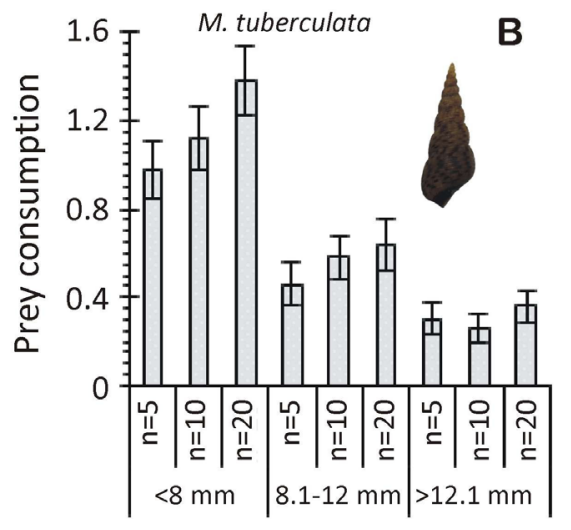

Prey size density

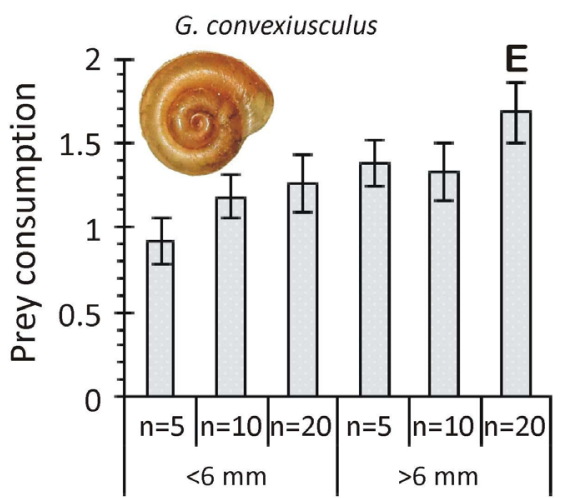

Prey size density

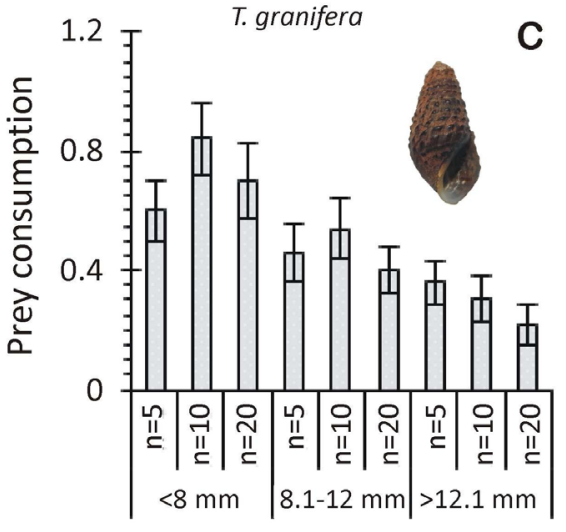

Prey size density

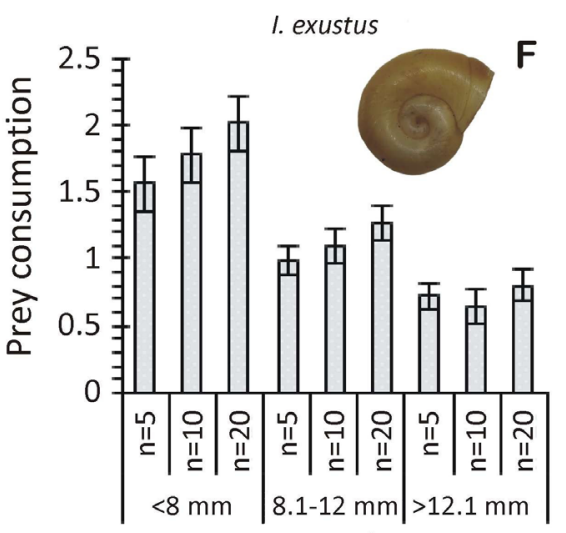

Prey size density

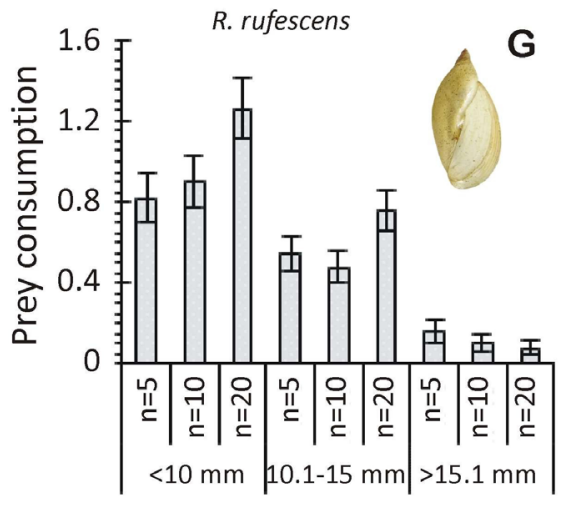

H

Prey size density

Fig. 1. The (Mean $\pm \mathrm{SE}$ ) prey consumption of the exotic predatory gastropod C. helena on the indigenous $B$. bengalensis (A), M. tuberculata (B), T. granifera (C), G. orcula (D), G. convexiusculus (E), I. exustus (F) and R. rufescens (G) with varying prey size and density in 48 hours. Subdued prey by the predator $C$. helena $(\mathrm{H})$, where the prey are: (i) B. bengalensis, (ii) M. tuberculata, (iii) T. granifera, (iv) G. orcula, (v) G. convexiusculus, (vi) I. exustus and (vii) R. rufescens 
ity rate is very low (Khan and Chaudhuri 1984). Consumption of the smaller sized $B$. bengalensis by $C$. helena can lead to higher mortality of juvenile snails which may result in the possible disruption of their reproduction, population growth and age structure. Similar consequences may be anticipated for M. tuberculata and T. granifera as they produce live offspring and the prey consumption of $C$. helena was higher against the smaller prey snails. Both $M$. tuberculata and $T$. granifera are intermediate hosts of several trematode parasites in the tropical countries of Africa and Asia (Dudgeon 1986; Glaubrecht 1996; Veeravechsukij et al. 2018) but since the twentieth century, they invaded different parts of the world (Appleton 2002; Duggan 2002; Rader et al. 2003). In the Indian perspective, $M$. tuberculata and $T$. granifera are an integral part of indigenous gastropod diversity and were readily consumed by the exotic predator $C$. helena in the present instance. Consideration of $C$. helena as the biocontrol agent of these snails (Oleh et al. 2018) may arise a question as the exotic species habitually kills non-target organisms. For instance, no evidence of the effectiveness of the release of Euglandina rosea to control the invasive African giant snail Achatina fulica was found but the predatory snail resulted in the extinction of many endemic snails (Cowie 1992). Similarly, the introduction of $C$. helena may not fulfil the desired objective more because of its generalized predatory nature. As the probable introduction of $C$. helena in non-native freshwater habitats can have negative impacts (Didham et al. 2007) on the native snail community, strict laws should be enforced regarding its uncontrolled sale ( $\mathrm{Ng}$ et al. 2016a) in aquarium pet shops. Considering the significant effects of biological invasions, the policymakers have restricted the import of several aquatic organisms in many countries (Díaz et al. 2012). On the other side, the household aquarium owners dispose the aquaria washings directly into the sink, drain or external fish ponds which may provide a high risk of non-native species invasion (Duggan 2010). Hence, the aquarium owners should be more aware of the potential harms due to the disposals and must be recommended to pour the aquaria wastes on garden and lawns which may minimize the risk of biological invasion (Duggan 2010).

The interaction of $C$. helena and other nongastropod prey, however, needs to be evaluated to decipher the possible impacts in the freshwater community if they ever colonize beyond the native range. As predicted for the exotic snail Pomacea diffusa (Aditya and Raut 2005) (erstwhile P. bridgesii), the introduction of the snail $C$. helena may bring about a interaction chain effect (Didham et al. 2007) as it can consume varied type of snails. In freshwater habitats, $C$. helena is known to scavenge and actively predate upon worms (Brandt 1974) and reported to reduce predation with growing organic matter (Oleh et al. 2018). Therefore, the predation rate on snails can be affected in the presence of alternative resources. Previously, native malacophagous invertebrates such as Sphaerodema rusticum and Glossiphonia weberi were reported as prospective predators against an introduced snail $P$. diffusa in India (Aditya and Raut 2001b, 2005). Likewise, further studies can be conducted with the native predators that may have the potential to predate upon and act as a biotic resistance towards the establishment of the exotic snail C. helena.

\section{Acknowledgements}

The authors thankfully acknowledge the constructive comments of the anonymous reviewer that enhanced the manuscript to its present state. The authors are grateful to the Head, Department of Zoology, University of Calcutta, Kolkata, West Bengal, India for the facilities provided. PP acknowledges CSIR-HRDG 09/028(1115)/2019-EMR-1, dated 06/08/2019 and AS acknowledges UGC Ref. No.: 761/(CSIR-UGC NET DEC. 2017), Roll- 354129, dated 17/01/2019 for financial support.

\section{References}

Aditya G., Hossain A., 2018, Valorization of aquaculture waste in removal of cadmium from aqueous solution: optimization by kinetics and ANN analysis, Appl. Water Sci. 8: \#68.

Aditya G., Raut S.K., 2001a, Food of the snail, Pomacea bridgesi, introduced in India, Curr. Sci. 80(8): 919921.

Aditya G., Raut S.K., 2001b, Predation of water bug Sphaerodema rusticum Fabricius on the snail Pomacea bridgesi (Reeve), introduced in India, Curr. Sci. 81(11): 1413-1414.

Aditya G., Raut, S.K., 2002a, Predation of water bug $S p$ haerodema rusticum on the freshwater snails, Lymnaea (Radix) luteola and Physa acuta, Veliger 45(3): 267269.

Aditya G., Raut, S.K., 2002b, Potential of the leech 
Glossiphonia weberi (Blanchard) in controlling the sewage snail Physa acuta Draparnaud, Curr. Sci. 83(11): 1317-1319.

Aditya G., Raut S.K., 2005, Feeding of the leech Glossiphonia weberi on the introduced snail Pomacea bridgesii in India, Aquat. Ecol. 39(4): 465-471.

Appleton C.C., 2002, First report of Tarebia granifera (Lamarck, 1816) (Gastropoda: Thiaridae) from Africa, J. Mollus. Stud. 68(4): 399-402.

Bhattacharya S., Chakraborty M., Bose M., Mukherjee D., Roychoudhury A., Dhar, P., Mishra, R., 2014, Indian freshwater edible snail Bellamya bengalensis lipid extract prevents $\mathrm{T}$ cell-mediated hypersensitivity and inhibits LPS induced macrophage activation, J. Ethnopharmacol. 157: 320-329.

Bogan A.E., Hanneman E.H., 2013, A carnivorous aquatic gastropod in the pet trade in North America: the next threat to freshwater gastropods, Ellipsaria 15(2): 18-19.

Botkin D.B., Saxe H., Araújo M.B., Betts R., Bradshaw R.H.W., Cedhagen T., Chesson P., Dawson T.P., Etterson J.R., Faith D.P., Ferrier S., Guisan A., Hansen A.S., Hilbert D.W., Loehle C., Margules C., New M., Sobel M.J., Stockwell D.B.R., 2007, Forecasting the Effects of Global Warming on Biodiversity, BioScience. 57(3): 227-236.

Brandt R.A.M., 1974, The non-marine aquatic mollusca of Thailand, Arch. Molluskenkd. 105: 1-423.

Burgiel S., Foote G., Orellana M., Perrault A., 2006, Invasive alien species and trade: integrating prevention measures and international trade rules, Center for International Environmental Law (CIEL) and Defenders of Wildlife, Washington, $54 \mathrm{pp}$.

Casas J., Hulliger B., 1994, Statistical analysis of functional response experiments, Biocontr. Sci. Technol. 4(2): 133-145.

Chan S.Y., 1997, Non-marine mollusks from Selangor, West Malaysia, with a comparison note on introduced species, Club Conchylia Informationen 29(1-2): 35-46.

Coelho A.R., Dinis M.T., Reis J., 2013, Effect of diet and stocking densities on life history traits of Clea helena (Philippi 1847) reared in captivity, J. Aquac. Res. Dev. 4(5): \#187.

Cowie R.H., 1992, Evolution and extinction of Partulidae, endemic Pacific island land snails, Phil. Trans. R. Soc., B. Biol. Sci. 335(1274): 167-191.

Devi P., Islam S., Das M., 2008, Ecology and biology of aquatic snails and their control: I. Comparative biology and development of five freshwater snails from Assam, J. Vet. Parasitol. 22(2): 9-12.

Díaz S., Smith J.R., Zaleski S.F., Murray S.N., 2012, Effectiveness of the California state ban on the sale of Caulerpa species in aquarium retail stores in southern California, Environ. Manag. 50(1): 89-96.

Didham R.K, Tylianakis J.M., Gemmell N.J., Rand T.A., Ewers R.M., 2007, Interactive effects of habitat modi- fication and species invasion on native species decline, Trends Ecol. Evol. 22(9): 489-496.

Dudgeon D., 1986, The life cycle, population dynamics and productivity of Melanoides tuberculata (Müller, 1774) (Gastropoda: Prosobranchia: Thairidae) in Hong Kong, J. Zool. 208(1): 37-53.

Duggan I.C., 2002, First record of a wild population of the tropical snail Melanoides tuberculata in New Zealand natural waters, New Zeal. J. Mar. Freshwat. Res. 36(4): 825-829.

Duggan I.C., 2010, The freshwater aquarium trade as a vector for incidental invertebrate fauna, Biol. Invasions. 12(11): 3757-3770.

Fagan W.F., Unmack P.J., Burgess C., Minckley W.L., 2002, Rarity, fragmentation, and extinction risk in desert fishes, Ecology 83(12): 3250-3256.

Glaubrecht M., 1996, Evolutionsökologie und Systematik am Beispiel von Süss- und Brack-wasserschnecken (Mollusca: Caenogastropoda: Cerithioidea): Ontogenese Strategien, paläontologische Befunde und Historische zoogeographie, Backhuys Publishers, Leiden, 499 pp.

Gutiérrez J.L., Jones C.G., Strayer D.L., Iribarne O.O., 2003, Mollusks as ecosystem engineers: the role of shell production in aquatic habitats, Oikos 101(1): 79-90.

Hossain A., Aditya G., 2013, Cadmium biosorption potential of shell dust of the fresh water invasive snail Physa acuta, J. Environ. Chem. Eng. 1(3): 574-580.

Hossain A., Aditya G., 2015, Biosorption of cadmium from aqueous solution by shell dust of the freshwater snail Melanoides tuberculata, Bioremediat. J. 19(1): 80-91.

Hossain A., Bhattacharyya S.R., Aditya G., 2015, Biosorption of cadmium by waste shell dust of fresh water mussel Lamellidens marginalis: implications for metal bioremediation, ACS Sustain. Chem. Eng. 3(1): 1-8.

[IUCN] International Union for Conservation of Nature, 2020, The IUCN Red List of Threatened Species. Version 2020-2 (Accessed 18 July 2020). Retrieved from https://www.iucnredlist.org/resources/summary-statistics\#Summary\%20Tables.

Kelly P.M., Cory J.S., 1987, Operculum closing as a defence against predatory leeches in four British freshwater prosobranch snails, Hydrobiologia 144(2): 121-124.

Khan R.A., Chaudhuri S., 1984, The population and production ecology of a freshwater snail Bellamya bengalensis (Lamarck) (Gastropoda: Viviparidae) in an artificial lake of Calcutta, India, Bull. Zool. Surv. India. 101(2/3): 59-76.

Li K., Liu Z., Hu Y., Yang H., 2009, Snail herbivory on submerged macrophytes and nutrient release: implications for macrophyte management, Ecol. Eng. 35(11): 1664-1667.

Lodge D.M., Williams S., Maclsaac H., Hayes K., Leung B., Reichard S., Mack R.N., Moyle P.B., Smith M., 
Andow D.A., Carlton J.T., McMichael A., 2006, Biological invasions: recommendations for policy and management, Ecol. Appl. 16(6): 2035-2054.

Mack R.N., Simberloff D., Lonsdale M.W., Evans H., Clout M., Bazzaz, F.A., 2000, Biotic invasions: causes, epidemiology, global consequences, and control, Ecol. Appl.10(3): 689-710.

Madsen H., Hung N.M., 2014, An overview of freshwater snails in Asia with main focus on Vietnam, Acta Trop. 140: 105-117.

Marijnissen S.A.E., Michel E., Kamermans M., Olaya-Bosch K., Kars M., Cleary D.F.R., 2008, van Loon E.E., Dolmen P.G.R., Menken, S.B.J., 2008, Ecological correlates of species differences in the Lake Tanganyika crab radiation, Hydrobiologia 615(1): 81-94.

McCullagh P., Nelder J.A., 1989, Generalized linear models. Monographs on Statistics and Applied Probability 37, Chapman and Hall, London-New York, 511 pp.

Mienis H.K., 2011, Will the uncontrolled sale of the snail-eating gastropod Anentome helena in aquarium shops in Israel result in another disaster for Israel's native freshwater mollusc fauna?, Ellipsaria. 13(3): 10-11.

Monks N., 2010, Natural born killers, Practical Fishkeeping 13: 14-15.

Ng T., Foon J.K., Tan S.K., Chan M.K.K., Yeo D., 2016b, First non-native establishment of the carnivorous assassin snail, Anentome helena (von dem Busch in Philippi, 1847), Bioinvasions Rec. 5(3): 143-148.

Ng T.H., Tan S.K., Wong W.H., Meier R., Chan S-Y., Tan H.H., 2016a, Molluscs for Sale: Assessment of Freshwater Gastropods and Bivalves in the Ornamental Pet Trade, PLoS One 11(8): \#0161130.

Novák J., Kalous L., Patoka J., 2020, Modern ornamental aquaculture in Europe: early history of freshwater fish imports, Rev. Aquacult. 12(4): 2042-2060.

Oleh M., Kyrylo B., Olena K., 2018, Biological and biomechanical principles of the controlling molluscs $\mathrm{Me}$ lanoides tuberculata (Müller 1774) and Tarebia granifera (Lamarck, 1822) in reservoirs of strategic importance, World Sci. News. 99: 71-83.

Padilla D.K., Williams S.L., 2004, Beyond ballast water: aquarium and ornamental trades as sources of invasive species in aquatic ecosystems, Front. Ecol. Environ. 2(3): 131-138.

Patoka J., Bláha M., Kalous L., Kouba, A., 2017a, Irresponsible vendors: Non-native, invasive and threatened animals offered for garden pond stocking, Aquat. Conserv. 27(3): 692-697.

Patoka J., Kopecký O., Vrabec, V., 2017b, Aquarium molluscs as a case study in risk assessment of incidental freshwater fauna, Biol. Invasions 19(7): 2039-2046.

Patoka J., Magalhăes A.L.B., Kouba A., Faulkes Z., Jerikho R., Vitule J.R.S., 2018, Invasive aquatic pets: failed policies increase risks of harmful invasions, Biodivers. Conserv. 27(11): 3037-3046.

Philippi R.A., 1847, Abbildungen und Beschreibungen neuer oder wenig gekannter Conchylien, Vol. II. Verlag Theodor Fischer, Cassel, 231 pp.

Pinowska A., 2002, Effects of snail grazing and nutrient release on growth of the macrophytes Ceratophyllum demersum and Elodea canadensis and the filamentous green alga Cladophora sp, Hydrobiologia 479(1-3): 83-94.

Rader R.B., Belk M.C., Keleher, M.J., 2003, The introduction of an invasive snail (Melanoides tuberculata) to spring ecosystems of the Bonneville Basin, Utah, J. Freshwat. Ecol. 18(4): 647-657.

Raut S.K., Aditya G., 1999, Occurrence of golden mystery snail Pomacea bridgesi (Gastropoda: Ampullaridae) in West Bengal, India, Curr. Sci. 77(11): 1389-1390.

Raut S.K., Bhaumik S., Das S., 1995, Occurrence of the snail Physa acuta Draparnaud in Calcutta, India, J. Bombay Nat. Hist. Soc. 92: 434.

Rixon C., Duggan I.C., Bergeron N., Ricciardi A., Macisaac, H., 2005, Invasion risks posed by the aquarium trade and live fish markets on the Laurentian Great Lakes, Biodivers. Conserv. 14(6): 1365-1381.

Rober A.R., Wyatt K.H., Stevenson R.J., 2011, Regulation of algal structure and function by nutrients and grazing in a boreal wetland, J. N. Am. Benthol. Soc. 30(3): 787-796.

Saha C., Pramanik S., Chakraborty J., Parveen S., Aditya G., 2016, Abundance and body size of the invasive snail Physa acuta occurring in Burdwan, West Bengal, India, J. Entomol. Zool. Stud. 4(4): 490-497.

Sin T.S., 2006, Evaluation of different species of fish for biological control of golden apple snail Pomacea canaliculata (Lamarck) in rice fields, Crop. Prot. 25(9): 1004-1012.

Strong E.E., Gargominy O., Ponder W.F., 2008, Global diversity of gastropods (Gastropoda: Mollusca) in freshwater, Hydrobiologia 595(1): 149-166.

Tripathy B., Mukhopadhayay A., 2015, Freshwater molluscs of India: an insight of into their diversity, distribution and conservation, [in:] Rawat M., Dookia S., Sivaperuman C. (eds), Aquatic Ecosystem: Biodiversity, Ecology and Conservation, Springer, New Delhi: 163-195.

Veeravechsukij N., Namchote S., Neiber M.T., Glaubrecht M., Krailas D., 2018, Exploring the evolutionary potential of parasites: Larval stages of pathogen digenic trematodes in their thiarid snail host Tarebia granifera in Thailand, Zoosyst. Evol. 94(2): 425-460.

Vinarski M.V., Aksenova O.V., Bolotov I.N., 2020, Taxonomic assessment of genetically-delineated species of radicine snails (Mollusca, Gastropoda, Lymnaeidae), Zoosyst. Evol. 96(2): 577-608.

Wilken G.B., Appleton C.C., 1991, Avoidance responses of some indigenous and exotic freshwater pulmonate snails to leech predation in South Africa, S. Afr. Tydskr. Dierk. 26(1): 6-10.

Wilson J.R.U., Dormontt E.E., Prentis P.J., Lowe A.J., Richardson, D.M., 2009, Something in the way you 
move: dispersal pathways affect invasion success, Trends Ecol. Evol. 24(3): 136-144.

Zheng Z., Jing L.V., Kaihong L., Jinyong Z., Xiasong L., 2011, The impact of snail (Bellamya aeruginosa) bio- turbation on sediment characteristics and organic carbon fluxes in an eutrophic pond, Clean (Weinh) 39(6): 566-571. 